Оригинални научни рад

УДК 821.112.2.09-1 Рилке Р. М. 78.067.26 Андерсон Л.

Примљен: 1. март 2021.

Прихваћен: 29. март 2021.

Јован М. Букумира ${ }^{{ }^{*}}$

https://doi.org/10.46630/phm.13.2021.39

Институт за књижевност и уметност

Београд

\title{
ФИГУРА АНЪЕЛА У ПОЕЗИЈИ Р. М. РИЛКЕА И МУЗИЦИ ЛОРИ АНДЕРСОН
}

Рад настоји да доведе у везу фигуру анђела из поезије Р. М. Рилкеа и музичких нумера Лори Андерсон, узимајући у обзир пре свега песничку збирку Девинске елегије и албум Чудни анђели. Унутар јудео-хришћанске традиције, из које потичу, анђели су схваћени као бестелесна божанска дејства, чисто духовна бића предивног гласа и гласници који обављају посредничку функцију између бога и човека. Савремена „културна индустрија“ пак допринела је пролиферацији и декоризацији представе анђела те доместификацији искуства оностраног. Насупрот томе, Р. М. Рилке и Лори Андерсон наглашавају нелагодну туђост „анђеоских порука“ и немогућност њихове потпуне асимилације од стране људи. Међутим, док је у поезији Р. М. Рилкеа анђео метафора највише индивидуалне могућности човека, посебно његових стваралачких односно песничких потенцијала, код Лори Андерсон се домен анђеоског деловања - трагом идеја Валтера Бенјамина - проширује и на аспекте друштвено-политичке солидарности и повезивања.

Кључне речи: Р. М. Рилке, Лори Андерсон, анђео, поезија, (популарна) музика

У извесности, анђео је излишан, Као музика у вакууму.

- Иван В. Лалић, КАКО ЈЕ УМРО

There is a crack in everything, That's how the light gets in. - Leonard Cohen, ANTHEM

\section{1. Увод: свет без бога}

Култура која познаје постојање анђела почива на снажним и неупитним метафизичким темељима. Будући да се анђели налазе у нераскидивој вези како с богом, коме су подређени, тако и са човеком, “jbukumira@yahoo.com.1 
кога штите - спајајући, попут трансверзале, основне полове значењске мреже људске културе, њено онострано и овострано исходиште њихово постојање представља својеврсни гарант извесности и пуноће таквог симболичког поретка. Међутим, преовлађујући процеси модерне секуларизације крећу се у супротном смеру, проналазећи своју крајњу тачку у чувеној тврдњи да је бог мртав, коју нам је крајем 19. века обзнанио Ниче. Бог није тек ишчезао са ове позорнице живота, наставља се у славном одломку о суманутом човеку, већ се ради о нечему озбиљнијем и, уједно, загонетнијем: бог је убијен и убили су га људи (NIČE 1984: 146147). Но, какво место у овако коренито уздрманом поретку преостаје анђелима? Могу ли они опстати у свету без бога, или су и они убијени? Може ли њихова егзистенција, у новим духовним приликама, задобити више иманентне него трансцендентне одлике? Сматрамо да нам поезија Р. М. Рилкеа и музика Лори Андерсон (Laurie Anderson) - чијем су најпре засебном, а потом и упоредном тумачењу посвећена средишња поглавља овог рада - могу пружити важне одговоре на ничеанску дијагнозу модерне културе.

Ничеов фрагмент, дакако, не бисмо смели да тумачимо као покушај рационалног објашњења природе бога, нити као наставак старих схоластичких расправа о (не)доказивости постојања божанског бића. Напротив, као што сугерише Хајдегер, бог овде стоји као ознака не само хришћанског врховног бића, него и целокупног натчулног света, то јест света идеалног и идејног - читаве метафизике. Натчулни свет, који нам је раније још могао бити егзистенцијалним темељем, будући да је даровао живот, идеале, законе, богове итд., испоставио се јаловим те сасвим неприкладним за нашу савремену животодавну вољу. Отуда Ничеов страствени бојни поклич против његових идеала. Надовезујући се на то, као и на познате Хелдерлинове стихове из „Хлеба и вина“, Хајдегер је, у свом есеју „Чему песници?“, могао закључити да ова прокламована смрт бога указује истовремено и на човеков заборав властите смртности: „Време је оскудно не само зато што је Бог мртав, већ и зато што смртници једва да су свесни чак и своје смртности и што једва да су у стању да с њом изађи на крај“ (HAJDEGER 2000: 213). Другим речима, губитком културног контекста у којем смо некада симболички обитавали измакнуто нам је тло под ногама не само када су у питању витални принципи, већ и када је реч о суочавању са нужношћу властите смрти - изостанак првог, показало се, тесно је повезан са заборавом потоњег.

Ничеова дијагноза о смрти бога, у чијем се средишту, заправо, налази прогноза о превредновању свих вредности, упућује на трагање за другачијим могућностима (духовног) утемељења. Немачки филозоф 
при том је у виду имао најпре уметнике, у чијем је стваралачком витализму пронашао потенцијал за стварање истински новог. Оно старо је изгнано и одбачено као бесплодна старудија која више никоме не може бити од користи, али испоставило се да није могло бити у потпуности заборављено. И након овог рашчишћавања духовног простора опстали су, ипак, неки обриси минулог, одређени облици, симболи, слике, натрухе идеја... Ни ова револуција није се могла зачети еx nihilo.

Ако је пак аутор Заратустре у нечему био у праву, онда је погодио да ћемо уметницима имати да захвалимо на изградњи нових духовних темеља. Њиховом заслугом опстали су (и) анђели. На почетку 20. века, малтене у сенци Ничеове смрти, фигура анђела добила је своје поново нађено достојанство у Девинским елегијама Рајнера Марије Рилкеа - на његовом крају, своју контексту примерену реактуелизацију на музичком албуму Чудни анђели Лори Андерсон.

\section{2. Анђели - између бога и човека}

Иакосведочанстваоњимапостојеиуполитеистичкимрелигијама, тек се јудео-хришћанство озбиљније позабавило овим необичним бићима, где је анђелима била посвећена и читава засебна теолошка (под) дисциплина, ангелологија. Ова је традиција на Западу била доминантна довољно дуго да и данас, иако више не живимо у „религиозној култури“, одређује и усмерава наше како духовно тако и визуелно поимање анђела, па ће нас посебно занимати само оне особености које нам могу бити од користи за тумачење Рилкеових и радова Лори Андерсон.

Етимологија речи, како излаже Јустин Поповић у одељку „Постанак духовног света“ првог тома своје капиталне Догматике (POPOVIĆ 2003: 252-266), потиче из старогрчког и латинског језика:

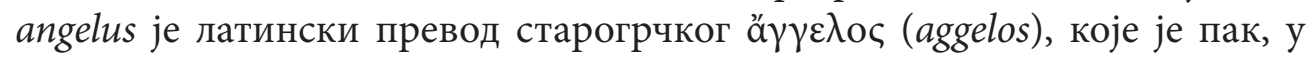
Септуагинти, искоришћено као превод старозаветног хебрејског ראָ: (mal'akh), што дословно значи гласник, посланик, изасланик, весник. У бројним теолошким расправама о природи анђела неоспорно је да се ради о бићима чија је суштина релациона: у космичкој хијерархији они заузимају место између бога и човека, и задужени су за њихову повезаност. Будући да су, према званичном доктринарном учењу, бестелесна, бесполна и чисто духовна бића, ближа су богу од човека, али су чак и они несравњиви са божијом савршеношћу. Августин је њихов назив објаснио функцијом коју обављају: они су анђели по ономе што раде, а духови по ономе што јесу. То су невидљиве, али осетљиве божанске силе, односно божанска дејства или чисти чинови божанске трансцеденције. Делатници у име бога и наместо бога - тако би се могла 
описати њихова вокација. Људима је ускраћено да спознају све њихове функције и дела, а дато им је да их открију само у виду гласника.

Анђео је, према томе, створење које обавља кључну улогу у видљивим и невидљивим пословима свеопштег божанско-људског општења. То што у овим каналима саобраћања уопште постоји потреба за анђелима-посредницима говори о постулираној немогућности непосредног божијег обраћања човеку. Бог је, такорећи, предубоко упао у своју трансценденцију и, осим у мистичким или екстатичким искуствима, постао недоступан смртницима с ове стране. Анђели наступају управо у овом зјапећем, глувом међупростору између бога и људи, покушавајући да највећу од свих знаних комуникацијских препрека између оне и ове стране премосте испуњавајући је смисленим порукама. Због тога, они не могу бити пуки преносници; чинећи поруку читљивом на оба краја ланца, они уједно морају бити и преводиоци с божијег на језик људи и обратно. А преводиоци су увек и тумачи. Тамо где нема директног контакта између бога и човека, ни слање порука не може се одвијати једнозначно. Медијатори, већ тиме што су бића мање савршена од бога, искривљују првобитну чистоту недвосмислености божије поруке, те је оно што напослетку стиже до човека само траг и слутња божанске речи. Анђели преводе и преносе поруку, али људи су ти који је морају растумачити. У том смислу анђео-весник заиста наликује Аполону из Хераклитовог фрагмента: нити откива нити скрива (божију поруку), већ само назначује, тј. навешћује.

Њихова близина богу и пребивање у натчулном имају још и ту предност у односу на човека што им омогућавају непрестано гледање бога лицем-у-лице. Нама је, пак, више стало до акустичког, тачније музичког аспекта њиховог оностраног соносферичног пребивалишта, како би рекао Петер Слотердијк. Анђели, наиме, предивно певају. Као и њихова дражесна невина лепота, тако је и узвишени глас један од израза хармоничности и блажености анђеоског рајског боравишта. Певање анђела је континуирано опевање боголикости поретка, чији духовни врт они радосно и поносно обделавају. Уосталом, код Филона Александријског може се пронаћи тврдња да се кроз анђеоски глас јавља сам божији Логос (KOPLSTON 1988: 498-499). Песмом и певом бог продорно одјекује кроз своја анђеоска створења. Није случајно да су глас и певање, својом нетелесношћу најближи духу (и даху), битна обележја бића чија је духовност безмало ненадмашива. Одатле потиче и песничка опчињеност, па и опседнутост анђелима, тим у исти мах саборничким и супарничким фигурама: ко год жели да пева барем делимице призива песму овог најдивнијег прапојца. 


\section{3. Масовна, популарна и висока култура}

Култура која своје темеље више није могла да пронађе у области религиозног ипак је, упркос свим Ничеовим насртајима, задржала доста (од) некадашњих симбола и ознака - али, морала је да их преиначи и преозначи. У савременој култури можемо да уочимо барем две супротстављене тенденције третирања фигуре анђела. Једну бисмо, условно говорећи, могли да поставимо на страну масовне културе, а другу на страну уметности.

Ово разликовање дугујемо америчким ауторима попут Двајта Мекдоналда (Dwight Macdonald) и Клемента Гринберга (Clement Greenberg). Мекдоналд је бранио вредности традиционалне, односно високе културе, тврдећи да нипошто не смемо мешати аутентичну и спонтано насталу народну са масовном културом, која представља појаву новијег датума и везана је за урбанизовано и индустријализовано друштво. Његова заједљива критика масовне културе потиче, с једне стране, из убеђења да ова представља изопачену мешавину народне и високе културе, и, с друге, из антикапиталистичког светоназора који у њој види наметнуто средство за експлоатацију широких маса од стране владајуће класе. Иако се не бисмо сложили с његовим крајње заоштреним и данас већ ноторним ставовима о масовној култури присетимо се, она је за њега „искључиво и директно роба за масовну потрошњу, као жвакаће гуме“, „паразитска, канцерогена израслина на високој култури“, те „млака, млохава култура за широке масе која прети да прекрије све својим надолазећим муљем“ (MEKDONALD 2012: 52, $54,56)$ - прихватићемо његову оцену да се, у већини случајева, ради о производима који су доступнији јер се лакше и брже како производе тако и конзумирају, те захтевају мање посвећености. С друге стране, Гринберг се бавио (културном) разликом између авангарде и кича - односно, високе и масовне културе - тврдећи да је потоња безмало нужна појава у индустријским друштвима Запада. Узроке за то проналази у новим животним условима огромног броја људи, који су након индустријске револуције прешли у велике урбане центре и у ту добили тек толико општег образовања да би се одвојили од народне, али недовољно да би били примљени у царство високе културе. Као и Мекдоналд, и Гринберг у кичу види процес културне експлоатације и уметничко-чулноискуственог затупљивања, па његове речи вреди цитирати у целости:

„Кич, користећи као сировину срозани и академизовани привид истинске културе, поздравља и култивише ову неосетљивост. Она је извор његовог профита. Кич је механички и функционише по формулама. Кич је искуство из друге руке и лажно узбуђење. Кич се мења с 
обзиром на стил, али остаје увек исти. Кич је отеловљење свега што је данас лажно. Кич се претвара да од својих корисника не захтева ништа осим новца - чак ни њихово време“ (GRINBERG 1989: 10). ${ }^{2}$

Вратимо ли се сада фигури анђела у савременој култури, лако ћемо закључити да масовна култура подразумева коришћење дотрајале и испражњене симболике анђела на колективном нивоу, док висока култура - односно, у нашем случају гринберговска авангардна уметност Рилкеа и Лори Андерсон - представља особену индивидалну уметничку ревизију и преиначење традицијом наслеђених фигура. Првом тенденцијом доминирају процеси објектификације и комодификације, а другом ревитализације и ресемантизације. Због тога уметнички успела обрада фигуре анђела, смерала она на то или не, има субверзивно дејство спрам устаљених и петрификованих представа божијих гласника.

Процес комодификације фигуре анђела можемо пратити још од позносредњовековних фигурица анђеоских дечака, такозваних putti, па све до данашњих статуица, бесомучног позивања на њихове библијске улоге, уврежених описа, серијски произведених приказа итд. Главна последица оваквог одношења према нечему што је важило за израз неприкосновене трансценденције јесте доместификација оностраности. Може се претпоставити да анђели нису доносили само добре и лагодне вести - иако их пре свега славимо као доноситеље оне најсрећније већ су морали наговештавати и оно опасно, злокобно или погубно. Доместификација њиховог бића покушај је свођења трансценденције на људску меру, и у том смислу представља кривотворење које ограничава и ублажава њихову трансцендентну моћ. Анђели су нам постали тек нешто више од пуке декорације, и приземљујући их на наша боравишта ми смо се „озбиљно удаљили од њихове изворне стварности, која је некада изазивала страхопоштовање“ (GERET 2015: 59). Али, ако је овај приземљени, припитомљени и осакаћени анђео онај с којим се може живети и који се може подносити, из њега је одстрањена неизвесност, дубина и величина, па се на такву фигуру - судећи према врхунским уметничким делима о којима ће у наставку бити речи - нипошто не сме пристати.

2 Гринберга, уосталом, спомињемо и због увида који потврђује тезу, изнету на Ничевом трагу у првом одељку овог рада, да је постепени распад претходне доминантне културе довео уметнике у незгдан положај, будући да су им нестанком стабилног културног контекста практично била одузета „средства за производњу“: „Сви принципи иза којих су стајали религија, ауторитет, традиција или стил доведени су у питање, те уметник или књижевник више није био кадар да процени реакцију своје публике на симболе и алузије којима се служи“"(GRINBERG 1989: 4). 
4. Р. М. Рилке: анђео индивидуалне поетизације

Треба одмах напоменути да фигура анђела, како се јавља у Рилкеовој поезији, стоји насупрот како хришћанско-религиозним учењима тако и горе анализираним процесима доместификације анђеоске симболике. Анђео је, поврх тога, једна од најзагонетнијих фигура Рилкеовог песништва уопште, и премда се појављивао и у понеким ранијим песмама, тек је у Девинским елегијама - танкој збирци која је настајала читавих десет година и која (уз Сонете посвећене Орфеју) међу коментаторима готово једногласно слови за његово најзрелије дело - добио централно место. Могли бисмо зато рећи да се Рилке сусрео са анђелом тек на врхунцу свог стваралаштва, што овој фигури свакако придаје додатно бреме значења.

Још се средином претходног столећа Ханс-Георг Гадамер реплицирајући својим огледом „Митопоетски преокрет у Рилкеовим 'Девинским елегијама'“ на тада већ увелико нарастао корпус тумачења Рилкеовог позног стваралаштва у религиозном кључу - одлучно и с правом успротивио ма каквом поистовећивању хришћанског и анђела Девинских елегија, упркос неким Рилкеовим двозначним разјашњењима из преписке (GADAMER 2002: 154). На самом почетку збирке, у „Првој елегији“, стоји:

„Ко би, да крикнем, ко би ме чуо из чета

анђеоских? па чак и да ме ненадно

привине неки на срце: ишчилео ја бих

од његовог снажнијег бића. Јер шта је лепота

ако не сам почетак страшнога, који смо таман

још кадри да поднесемо, па му се тол'ко

дивимо само зато што с нехајним презиром неће

да нас разори. Сваки је анђео страшан“ (RILKE 2011: 9).

Лирски субјект Рилкеових елегија не дозива никакво метафизички трансцедентно створење, које би требало да се с божанских висина оностраности спусти до њега и утоли му муке. А још мање би се могло рећи да то створење представља изасланика хришћанског бога. Анђео је овде, следимо ли Гадамера, ознака пуноће чувствовања, односно досегнуте извесности пунине осећајног живота, али и инхерентна потенција самог човека, те стога надире из најдубљих душевних слојева лирског субјекта:

„Анђео је надљудско биће и највиша могућност самог људског љубљења [...] пред којом оно отказује и коју није кадро да оствари јер је човек многим условљен и тако учињен неспособним за једнозначност и неограничену преданост свом чувствовању“" (GADAMER 2002: 156-156). 
Али,немачкихерменеутичар, премдапознатпо интерпретативној уздржаности, није у праву када одлази предалеко у одбијању хришћанске симболике. Иако сасвим извесно није део божијег посланства, Рилкеов анђео несумњиво задржава функцију изасланика, само што је овог пута, такорећи, обрнут смер његовог деловања. Овај изасланик-инсајдер навешћује нам нас саме: то је од нас самих послат емисар у неизвесне пределе сопственог чувствовања, али такав који боље види и поузданије извештава о овим дубинским душевно-геолошким путовањима. Утолико нам и он, као и повереник божије поруке, мора пренети, превести и предочити оно што је видео служећи се језиком и сликама за које се можемо надати да ћемо их разумети.

Помоћу анђела, сугерише нам Рилке, успевамо да видимо себе даље од себе самих, односно кадри смо да наслутимо смислено и коначно испуњење властитог бића, као и његово утапање у шири, космички поредак. Међутим, да је то виђење-наслућивање застрашујуће и тешко подношљиво, Рилке истиче на најбитнијим местима песама, као на пример у „Другој елегији“:

„Сваки је анђео страшан. Па ипак, јао мени,

ја вас опевам, готово смртоносне

птице душе, а свестан сам шта сте ви“" (RILKE 2011: 13).

Али, зашто је ово страшно и због чега је већ и сама помисао на анђела потенцијално погубна? Јер се он рађа из великог и најпре несхватљивог потреса, при којем наше свакодневно битисање узмиче пред непојмљивом снагом која га надилази - јер анђео надире као незадржива бујица и расветљава нам пут неподношљиво снажно. По томе, слободно можемо рећи да Рилкеов анђео не губи нимало од оне силине која је карактерисала хришћанске богопосланике. Овај анђео је, као код Хелдерлина, спој опасног и спасоносног, те представља могућност да се у хајдегеријанском бездану постојања, испуњеном стрепњом, наслути спасоносна искра извесног, она која потиче из нас самих.

Међутим, порука коју примамо од анђела није сасвим разазнатљива и саморазумљива, и - у томе лежи још један кључни увид из „Прве елегије“ - потребни су песници да је рашчитају и пренесу даље.

„... и довитљиве звери примећују већ да нисмо поуздани нити као код куће у тумаченом свету...“ (RILKE 2011:9)

Дешифровањесваке,па ианђеоскепорукеподразумева могућност погрешке, а бити принуђен на перманентно тумачење значи увек унапред рачунати на неизвесност, што чини да у „тумаченом свету“, упркос свим 
(херменеутичким) напорима, не можемо пронаћи жуђени завичај. Неки знаци нам увек измичу и живот у рају поуздано протумачљивог света остаје нам вазда недостижан. Песници, пак, наступају као осетљиве струне вичне пажљивом ослушкивању анђеоских порука. Тек тако и они, делом, преузимају функцију анђела и својом песмом ентузијастично шире даље примљену благовест, по наредби из „Девете елегије“:

„Величај анђелу свет, не неизрецив, пред њим се не можеш осећањима величанственим хвастати; у свемиру, где он осећа осећајније, ти си новајлија. Стог му покажи све што је једноставно, оно што, обликовано од поколења многих, ко наша сопственост живи крај руке и у погледу. Реци му ствари. Он ће стојати све зачуђенији, ко ти крај римског ужара или лончара с Нила“ (RILKE 2011: 43).

Није стога погрешно у Рилкеовом анђелу видети „песничко заснивање бића“. 3 Песник пред анђелом испуњава свој задатак, пред њим пева о ономе земаљском и овосветовном, што анђелу ипак остаје страно, и пред њим очекује да ће достићи дуго жељени преображај свог бића, који га утемељује. Као што је Петер Слотердијк приметио поводом једне друге Рилкеове песме, „Аполоновог архајског торза“, аустријски песник успоставља у оквиру песама вертикалну напетост. Анђео је биће апсолутне вертикалности, а тиме и неопозивог ауторитета, чији су искази усмерени ка суштинској промени песниковог бића: „То је ауторитет једног другог живота у овоме. Он ме затјече у суптилној инсуфицијентности, која је старија и слободнија од гријеха. Она је моје најинтимније 'још не“ (SLOTERDIJK 2011). Читава позна Рилкеова поезија покушај је попуњавања ове застрашујуће празнине у срцу бића и приближавања идеалу анђеоске испуњености

\section{5. Лори Андерсон: анђели колективне солидарности}

Музички опус Лори Андерсон не би требало посматрати сасвим одвојено од њених других пројеката, будући да ова збиља свестрана америчка уметница ${ }^{4}$ непрестано ради на томе да у своја дела инкорпорира

3 За доследно спроведено хајдегеријанско читање елегија види ANDREJIĆ 2013: „Да би допрео до анђела човек мора да изведе преокрет или прелазак од непесничког (владавине техничког смисла културе) ка песничком начину постојања...“ (138).

4 О њеној свестраности и задивљујућем опсегу уметничког рада као добар показатељ нам може послужити Појмовник сувремене умјетности, у којем је Лори Андерсон споменута под следећим одредницама: андрогин, аутобиографска уметност, поставангардне музичке продукције, езотерички и егзотерички модернизам, постфеминистички перформанси, фотографија у функцији документа, хиперестетско, постмодернистичка 
средства, поступке и потенцијале различитих уметности. Али, она објављује и „обичне“ музичке албуме, па нема разлога да их, барем за потребе овог есеја, сагледавамо искључиво у контексту целовитости опуса; ти албуми (по)стоје и као засебне и самосталне целине.

Дискографија Лори Андерсон засад стоји на седмом подеоку када је реч о класичним студијским издањима, али та бројка брзо нараста уколико се узму у обзир и live или spoken-word албуми, копродукције, колаборације и компилације, те сав онај материјал наснимљен углавном током или за потребе многобројних перформанса. Најинтензивнији период њеног „музицирања“ свакако су осамдесете, декада у којој је објавила своје најзначајније плоче. Дотад је имала свега неколико синглова разбацаних по малобројним do-it-yourslef компилацијама, али почев од 1981. године, сарадње са Џоном Ђорном (John Giorno) и Вилијамом Бароузом те амбициозне турнеје Сједиюене Државе уживо (United States Live), Андерсон је безмало сваке године до краја деценије избацивала по један албум. Утолико се Чудни анђели (Strange Angels), објављени 1989. године, заиста могу сматрати довршетком ове доминантно (алт/поп) музичке фазе њеног стваралаштва, нарочито ако имамо у виду да је након тога објављивала самосталне албуме уз све веће временске размаке (1994-2001-2010).

Већ својим местом унутар дискографског низа Чудни анђели праве хипотетичку паралелу с Рилкеовим Девинским елегијама: и код ње и код њега анђели су фигуре од средишњег значаја управо у оним најбитнијим и најбољим издањима. Наравно, обоје спорадично спомињу анђеле и раније (или, у њеном случају, касније), али нигде у толикој мери и никад с толиким значајем као у наведеним делима. Занимљиво је, у овом контексту, истаћи да се први анђео у њеном опусу појављује у песми „Анђео гравитације“ („Gravity's Angel“) с албума Господин срияоломаи (Mister Heartbreak). ${ }^{5}$ Иако је више пута истицала да јој је Мелвил најдражи књижевник, овде се очито ради о алузији на Пинчонов роман Дуга гравитаuије (Gravity's Rainbow). Сличан дијалог између лирског субјекта и анђела одиграће се и у каснијој песми „Мрачни анђео“ („Dark Angel“) с албума Живот на струни (Lif on a String) - и, колико нам је познато, никад више Лори Андерсон неће дозивати те „смртоносне птице душе“ у

компјутерска уметност, масовна култура и висока уметност, наративна фотографија, перформанс, перверзија, после покрета, постфеминистичка уметност, постконцептуална уметност, постмодерна музика, приватни симбол, рок глазба и култура, субјект, техноперформанс, текстуална уметност, видео уметност, звучни рад (ŠUVAKOVIĆ 2005: 811).

5 Исти албум отвара једна од њених познатијих нумера, „Шаркијев дан“ („Sharkey’s Day“), у којој В. Бароуз чита стихове, а у једном тренутку прави се алузија на испразне схоластичке расправе о томе колико анђела може да се смести на врху игле. 
своје песме. Чудни анђели стоје на размеђи та два издвојена случаја.

„Анђео гравитације“ говори о гордости, успостављајући вертикално позиционирање субјекта, који се егзистенцијално примарно оријентише на оси горе-доле (а не лево-десно), тражећи своје боравиште имеђу неба и земље, а свој идентитет између бога (или анђела) и осталих овоземаљских створења. Гордост смртника укроћена је визијом анђела. Но, док јој у тој песми, малтене ауторитетом објаве, изриче упозорење о нужној повезаности висине узлета и дубине пада, анђео друге песме - означен као „мрачни“ - постаће метафора стваралаштва. По томе функција овог анђела наликује оној коју има код Рилкеа: анђео само привидно долази однекуд споља, док се уистину помаља из дубине нашег стваралачког (и често заборављеног) бића; он је подстрекивач могућности да се нађемо испред и изван себе самих, да макар за корак будемо ли „за дах одважнији“, како каже Рилке - наступимо с оне стране сопствених граница.

Ако су се у споменутим песмама анђели јављали искључиво самостално и појединачно, не би било претерано рећи да на Чудним анђелима имамо посла са правим хором анђела, што потврђује већ множина из наслова. Они се ту појављују у свој својој величини и достојанству, због чега овај албум и представља највишу тачку опевања анђела у опусу Лори Андерсон.

Очекивано, насловна нумера нуди у натрухама дату личну ангелологију. Није да ту директно сазнајемо ко су ти чудни анђели, како изгледају или одакле долазе, али ситуација дата у песми нам доста говори о томе шта они чине за нас у овом свету, како дејствују - јер они су пре свега дејствујуће силе и чинови, актери и агенси - и шта тиме постижу.

„They say that heaven is like TV,

A perfect little world that doesn't really need you“ (ANDERSON 1989).

Насупрот (телевизијском) рају, из којег смо одавно изгнани као потпуно сувишни, ми припадамо овом свету неизвесности, бриге и стрепње. Стога не изненађује да је, баш поводом ових стихова, упоредивши их са нумером „Рај“ („Неaven“) бенда Talking Heads, један критичар изнео тезу о „два различита приступа, два схваћања постмодерног“, при чему би „амерички“ био карактеристичан за високотехнолошко друштво, а „европски“ за „стари“ свет и даље опседнут емоцијама и страстима (KRŠIĆ 1991: 87). Али, заокрет који се дешава како песма одмиче доноси провалу оног неспутано животног и исконског у окоштали свакодневни живот. ${ }^{6}$ И тада се појављују анђели, као најављивачи („Here they come“)

6 Не би било неосновано претпоставити да је овакав завршетак инсипирисан филмом Вима Вендерса Небо над Берлином (Der Himmel über Berlin), који је изашао две године 
нечега непознато великог („larger than life“), што тек треба да се случи. Испоставља се да је реч о пријатељској целовечерњој гозби. Као и код Рилкеа, анђели не долазе као божији гласници: све се одвија с ове стране, рај је на почетку само иронично призван, никакава порука не стиже из некаквог претпостављеног божанског извора. Али, збива се нешто што надилази уобичајено живљење, па Андерсон посеже за фигуром анђела како би приказала силину и неочекиваност тог збивања. За разлику од Рилкеа, овде имамо посла са више анђела и са више појединаца, и наместо (интра)субјективног долази до интерсубјективног чувствовања. Чудни анђели Лори Андерсон весници су истинске могућности постојања (додуше, малобројне) заједнице утемељене на искрености и апсолутној отворености. Таква солидарност ретко се доживљава, али када се догоди уздамо се да ће нам анђели држати очи отвореним за будуће прилике.

Овакво ревизионистичко преокретање Рилкеовог искључиво особног анђела у биће које израста из међусобног односа више особа код Лори Андерсон можемо тумачити и из перспективе интермедијалности, посебно собзиром нато да серади о музичкомпреобликовањурелигиозног мотива из поетске творевине. Према Ирини Рајевски, интермедијалност је оквирна ознака за свако прекорачење граница између медија, у оквиручега је могуће издвојити три основне поткатегорије: медијску транспозицију, комбинацију медија и интермедијалне референце. Последњој групи припадају поступци као што су музикализација књижевности, екфраза, алузије на сликарство у филму и слично, па „интермедијалне референце стога треба разумети као стратегије творења смисла које доприносе општем значењу дела“" (RAJEVSKI 2005: 52-53). Имајући ову дефиницију у виду, можемо закључити да глас рилкеовског анђела, иако преобликован и преозначен, дубоко одзвања у музици Лори Андерсон, стварајући тако додатни значењски слој њених песама.

Једна друга песма ове америчке музичарке, „Некадашњи сан“ („The Dream Before“), може нам послужити као путоказ за рашчитавање могућег утицаја, барем када је реч о анђелима, и за успостављање значајне посредничке фигуре између Рилкеа и Андерсон. На њу је још пре двадесетак година пажњу скренуо Борис Буден, када се у есеју „Immanuel Kant i milijun Toyota“, полемишући о односу „високе“ и „ниске“ културе, духовито и не без разлога упитао:

„A zašto taj Lasićev hrvatski intelektualni šegrt Hlapić ne bi primjerice otišao u striptease lokal, naime tamo gdje je Umberto Eco još šezdesetih našao Platona, zašto ne bi sjeo u kino da na filmu proučava Jacquesa Lacana, ili se kod Woody Allena raspitao za Ereuda, odnosno Waltera Benjamina slušao пре овог албума. Радња филма прати двојицу анђела док бораве у Берлину, при чему се један од њих заљубљује у смртницу, што покреће низ питања о предностима и манама смртничке и анђеоске егзистенције. 
na koncertima Laurie Anderson?“ (BUDEN 1998: 252).

Овде, дакле, Андерсон експлицитно реферише на немачког мислиоца, и то на познати одељак о анђелу историје из „Историјскофилозофских теза“. Наведени текст представља сажето, али оригинално и надахнуто ишчитавање загонетне слике Паула Клеа „Angelus Novus“ у марксистичко-месијанском кључу (BENJAMIN 1974: 79-90). „Некадашњи сан“ није ништа друго доли постављање сцене за утеловљење тих теза. Типски ликови Ивице и Марице, уприличени овде као сасвим просечан берлински брачни пар, доживљавају кризу свог односа која их води, како нам сугеришу увек елиптични и ишчашени стихови Лори Андерсон, до преиспитивања целокупног дотадашњег живота. И наједном, њихов разговор прераста у дијалогизовано цитирање Бенјаминовог одломка тако их походи анђео.

„He said: History is a pile of debris

And the angel wants to go back and fix things

To repair the things that have been broken

But there is a storm blowing from Paradise

And the storm keeps blowing the angel

Backwards

Into the future

And this storm, this storm

Is called

Progress“ (ANDERSON 1989).

Но, главна функција Бенјаминовог посредовања фигуре анђела између Рилкеа и Андерсон, по нашем мишљењу, лежи узаокрету од личног ка политичком. Рилкеов је анђео, посве у складу с његовом поетиком, израз највише (поетске) могућности човековог најунутарњијег бића, оног највластитијег а тиме и најближег поретку космоса и природе дакле, оног најудаљенијег од других људи. Анђео за Рилкеа има истинског смисла само утолико уколико јесте оно појединачно најсвојственије, и тек уколико тиме заобилази конвенцијама спутане међуљудске односе и утапа индивидуу у космичко јединство. Гершом Шолем (Gershom Scholem), у свом тумачењу Бенјаминовог односа према разним фигурама анђела, као главну тезу изнео је обрт који се у том односу догађа између херметичног кратког записа „Agesilaus Santander“ (1932) и постхумно објављених „Историјско-филозофских теза“ (1940). Тек је у потоњем тексту Бенјамин проговорио о анђелу с обзиром на колективитет а не индивидуалитет (ŠOLEM 2008: 165). Након што је углавном служио као средство за превладавање личних проблема, ${ }^{\bowtie}$ анђео се тек ту појављује као месијанска фигура која долази да избави све(т). Као и код Рилкеа, 
Бенјаминов анђео посредује однос према оностраном и невидљивом, али наступа као избавитељ читаве скупине људи - потлачене класе. Лори Андерсон задржаће и рилкеовски и бенјаминовски аспект анђеоског бића, што ће јој омогућити да истакне политичке димензије анђеоске епифаније.

Анђеоске чете, не у својим догматским хришћанским одорама, откривају се лирском субјекту и у песми „Рамон“:

„Last night I saw a host of angels

And they were all singing different songs

And it sounded like a lot of lawnmowers

Mowing down my lawn“ (ANDERSON 1989).

Скупина анђела више не пева једногласно и хармонично сваки пева своју песму, и у таквој какофоничној гомили они подсећају на брујање косилица за траву. Пре него да у томе видимо само одбојну бесмислену буку и покушај доместификације звука оностраних створења, радије бисмо приметили да је, чак и у овој дисхармоничној анђеоској констелацији, у питању израз како личног тако и друштвеног стања. Поново, анђели не доносе никакву онострану поруку; поново, њихово биће није ништа одређеније концептуализовано. Они, у ствари, служе као својеврсна фигура згушњавања: анђели прибирају у себи и личнопсихолошка и друштвено-историјска збивања и чине их очигледнијим. У томе и лежи њихово посланство - у овом навешћивању актуелног, али нама још недовољно видљивог збивања, у овој могућности да нам предоче и учине прозрачним оно што (нам) се тренутно дешава, раскривањем онога што потајно надире. Није реч ни о каквој будућности, већ о сабирању садашњости у себе саму ради разоткривања. Анђели и овде навешћују назначујући а не дословно разоткривајући, те се лирском субјекту у наставку песме отвара низ питања на која не успева да одговори. Али барем је јаснија улога анђела: они нам помажу да поставимо истинска питања.

\section{6. Закључак}

У оном Рилкеовом писму у којем се даје (само)тумачење природе анђела каже се да је реч о створењу које је већ извршило преображај којем и ми, као људи, тежимо - из видљивог у невидљиво (HAJDEGER 2000: 246). Анђела је могуће наслутити само онда када је човеково чувствовање најинтензивније и када тежи да се стопи с невидљивим. Рилкеов анђео постоји на тој граници између чулног и натчулног света, и то настајући из дубине првог како би се спокојно настанио у потоњем, а песник нам поручује да би и вага на којој човек себе одмерава требало 
напослетку да превагне на исту страну. Речју, Рилкеов анђео навешћује оно скорашње невидљиво, у које ће се ово садашње видљиво напослетку преобразити. Лори Андерсон је на посве другачији начин инкорпорила анђеоску симболику у своје песме. Није да они код ње немају никакве везе с невидљивим; они долазе у тренуцима „пространијим од живота“ и симболички отеловљују оно што га надилази и обузима. Али, осим што су бестелесна отеловљења невидљивог, они су уједно и прибирућа утеловљења која омогућују да се прикаже суштина видљивог. Одатле можемо извући још једно објашњење чудности „чудних анђела“: насупрот Рилкеовим невидљивим створењима они стоје као својеврсна згуснутост свег видљивог.

На крају, важно је на овом примеру истаћи разлику у односу ових уметника према популарној култури. Рилке се одлучно супротставио надирућој инфлацији производа масовне технологизоване културе својом крајње идиосинкратичном ревитализацијом окошталих симбола једне културе на заласку. Став који је заузео био је, у најмању руку, аристократски надмен спрам популарне културе и, истовремено, религијски пожртвован с обзиром на властиту духовност и стваралаштво. Рилке је неговао култ осамљеног ствараоца и повученог аскете, верујући да ће само тако успети да чује и досегне оне лично-душевне и природнокосмичке дубине којима је тежио. Застрашујући и колосални анђео његових елегија израз је крајње индивидуалне силине и моћи човекових (нарочито песничких) потенцијала, оних у којима се безмало одражава снага космичког поретка, и постављен је као крајњи циљ вечитог стремљења према области невидљивог и натчулног. Лори Андерсон, међутим, уопште није презала од уплитања у све противречности које нужно доносе савремена популарна култура и степен (и смер) друштвеног развоја. Иако је своју уметничку репутацију стекла у уском и пробраном кругу њујоршке „авангардне секте“, она је убрзо потом - стварајући „питкије“ и за ширу публику пријемчивије албуме, но у исти мах не одустајући ни од „високих“ авангардистичких претензија - пронашла начин да и сама постане активни судионик популарне културе. То је лепо сажео њен музички сарадник на Чудним анђелима: „Она је ту упала сасвим изван етаблираних колосека поп музике и обратила се на један нов, узбудљив начин широј публици, а не само авангардној мањини“ (TORN 1999). Анђели који на том албуму „певају само за њу“ ипак нису створења рилкеовски везана само за њену индивидуалност, већ је окрећу према ближњима или страдалницима, појављујући се у тренуцима изузетне отворености и рањиве изложености других. Они су својеврсне кристализације тих граничних ситуација, чију дирљиву лепоту навешћују и опевају, постајући тако сведоци - на крају крајева, као и код Рилкеа - 
најунутарњијег преображаја нашег бића.

Напослетку, остаје нам само да жалимо што Лори Андерсон није углазбила Рилкеову „ангелетску“ поезију док је била на врхунцу своје музичке каријере, када су анђели још увек походили њене албуме. Чини нам се да је сада за тако нешто прекасно, а не верујемо ни да би било пожељно - мада, када је она у питању, не презамо ни од каквих изненађења. Довољно је, за сад, што је тај потенцијални и плодотворни сусрет омогућен барем у духовним пројекцијама њихове заједничке публике.

\section{Цитирана литература}

ANDERSON 1989: ANDERSON, Laurie. Strange Angels. Warner Bros. Records, 1989 [CD]. <https://genius.com/albums/Laurie-anderson/Strange-angels $>$. 26. 2. 2021.

ANDREJIĆ 2013: ANDREJIĆ, Slađana. „Rilkeov anđeo kao metafora pesničkog 'zasnivanja bića'“. Sveske: časopis za književnost, umetnost i kulturu, god. 24, br. 109 (2013): str. 133-139. [orig.] АНДРЕЈИЋ, Слађана. „Рилкеов анђео као метафора песничког 'заснивања бића'“. Свеске: часопис за къижевност, уметност и културу, год. 24, бр. 109 (2013): стр. 133-139.

BENJAMIN 1974: BENJAMIN, Walter. Eseji. Prev. Milan Tabaković. Beograd: Nolit, 1974.

BUDEN 1998: BUDEN, Boris. Barikade 2. Zagreb: Arkzin, 1998.

GADAMER 2002: GADAMER, Hans-Georg. Filozofija i poezija. Prir. Milo Lompar, prev. Saša Radojčić. Beograd: Službeni list SRJ, 2002.

GERET 2015: GARRETT, Greg. Entertaining Judgment: The Afterlife in Popular Imagination. Oxford: Oxford University Press, 2015.

GRINBERG 1989: GREENBERG, Clement. Art and Culture: Critical Essays. Boston: Beacon Press, 1989.

HAJDEGER 2000: HAJDEGER, Martin. Šumski putevi. Prev. Božidar Zec. Beograd: Plato, 2000. [orig.] ХАЈДЕГЕР, Мартин. Шумски путеви. Прев. Божидар Зец. Београд: Плато, 2000.

KOPLSTON 1988: KOPLSTON, Frederik. Istorija filozofije. Tom I: Grčka i Rim. Prev. Slobodan Žunjić. Beograd: BIGZ, 1988.

KRŠIĆ 1991: KRŠIĆ, Dejan. „Laurie Anderson“. Moment: časopis za vizuelne medije, br. 20 (1991): str. 87-89.

MEKDONALD 2012: MEKDONALD, Dvajt. „Teorija masovne kulture“. U: Studije kulture: zbornik. Ur. Jelena Đorđević, prev. Vera Vukelić. Beograd: Službeni glasnik, 2012: 51-65.

NIČE 1984: NIČE, Fridrih. Vesela nauka. Prev. Milan Tabaković. Beograd: Grafos, 1984.

POPOVIĆ 2003: POPOVIĆ, Justin. Dogmatika pravoslavne crkve I. Beograd: Zadužbina "Sveti Jovan Zlatousti“" Ave Justina Ćelijskog; Valjevo: Manastir Ćelije, 2003. [orig.] ПОПОВИЋ, Јустин. Догматика православне иркве I. 
Београд: Задужбина „Свети Јован Златоусти“ Аве Јустина Ћелијског; Ваљево: Манастир Ћелије, 2003.

RAJEVSKI 2005: RAJEWSKY, Irina O. „Intermediality, Intertextuality, and Remediation: A Literary Perspective on Intermediality“. Intermediality: History and Theory of the Arts, Literature and Technologies, No. 6 (Fall 2005): str. 43-64. RILKE 2011: RILKE, Rajner Marija. Soneti i elegije. Prev. Branimir Živojinović. Beograd: Mali vrt, 2011.

ŠOLEM 2008: SCHOLEM, Gerschom. „Walter Benjamin i njegov anđeo“. U: Walter Benjamin. Novi anđeo. Prev. Snješka Knežević. Zagreb: Antibarbarus, 2008: $127-171$.

SLOTERDIJK 2011: SLOTERDIJK, Peter. „Naredba iz kamena“ [„Der Befehl aus dem Stein. Rilkes Erfahrung“. Du mußt dein Leben ändern. Frankfurt am Main: Suhrkamp Verlag, 2009]. Prev. Mario Kopić. Peščanik, 24. 11. 2011. <https:// pescanik.net/naredba-iz-kamena-2/>. 26. 2. 2021.

ŠUVAKOVIĆ 2005: ŠUVAKOVIĆ, Miško. Pojmovnik suvremene umjetnosti. Zagreb: Horetzky, 2005.

TORN 1999: THORNE, Mike. „The Making of Laurie Anderson's 'Strange Angels““. Stereo Society (January 1999). <https://stereosociety.com/strangeangels>. 26. 2. 2021.

Jovan Bukumira

\section{FIGURE OF ANGEL IN POETRY OF R. M. RILKE AND MUSIC OF LORIE ANDERSON}

The aim of the paper is to comparatively explore the connections between the figure of an angel in the poetry of R. M. Rilke and the music of Laurie Anderson, primarily focusing on the Duino Elegies collection and the Strange Angels album. Within the Judeo-Christian tradition, from which they originate, angels are understood as immaterial divine energies, purely spiritual beings with a beautiful voice, and messengers i.e. mediators between god and man. However, contemporary „cultural industry" has contributed to the enormous proliferation of the angelic representation, reducing it to mere decoration, and to the domestication of the experience of what lies beyond. In contrast, R. M. Rilke and Laurie Anderson emphasize the unheimlich feature of "angelic messages“, and the human impossibility to completely assimilate them. But, while in the poetry of R. M. Rilke the angel functions as a metaphor for the highest individual possibilities of human, especially its creative and poetic potentials, in songs of Laurie Anderson this domain of angelic agency - following the ideas of Walter Benjamin - expands also to aspects of socio-political relations and mutual solidarity.

Keywords: R. M. Rilke, Laurie Anderson, angel, poetry, (popular) music 